\title{
Combination of 12-O-tetradecanoylphorbol-13-acetate with diethyldithiocarbamate markedly inhibits pancreatic cancer cell growth in 3D culture and in immunodeficient mice
}

\author{
HUARONG HUANG ${ }^{1}$, KAJIA CAO ${ }^{2}$, SAQUIB MALIK ${ }^{3}$, QIUYAN ZHANG ${ }^{1}$, DONGLI LI $^{1}$, RICHARD CHANG $^{3}$, \\ HUAQIAN WANG ${ }^{1}$, WEIPING LIN ${ }^{1}$, JEREMIAH VAN DOREN ${ }^{3}$, KUN ZHANG $^{1}$, ZHIYUN DU $^{1}$ and XI ZHENG ${ }^{1,3}$ \\ ${ }^{1}$ Allan H. Conney Laboratory for Anticancer Research, Guangdong University of Technology, Guangzhou, \\ Guangdong 510006; ${ }^{2}$ Department of Nasopharyngeal Cancer, Sun Yat-sen University Cancer Center, Guangzhou, \\ Guangdong 510060, P.R. China; ${ }^{3}$ Department of Chemical Biology, Ernest Mario School of Pharmacy, \\ Rutgers, The State University of New Jersey, Piscataway, NJ 08854, USA
}

Received October 27, 2014; Accepted March 3, 2015

DOI: 10.3892/ijmm.2015.2163

\begin{abstract}
The aim of the present study was to determine the effects of 12-O-tetradecanoylphorbol-13-acetate (TPA) and diethyldithiocarbamate (DDTC) alone or in combination on human pancreatic cancer cells cultured in vitro and grown as xenograft tumors in nude mice. Pancreatic cancer cells were treated with either DDTC or TPA alone, or in combination and the number of viable cells was then determined by trypan blue ecxlusion assay and the number of apoptotic cells was determined by morphological assessment by staining the cells with propidium idiode and examining them under a fluorescence microscope. Treatment with DDTC or TPA alone inhibited the growth and promoted the apoptosis of pancreatic cancer cells in a concentration-dependent manner. These effects were more prominent following treatment with TPA in combination with DDTC than following treatment with either agent alone in PANC-1 cells in monolayer cultures and in 3 dimensional (3D) cultures. The potent effects of the combination treatment on PANC-1 cells were associated with the inhibition of nuclear factor $-\kappa \mathrm{B}(\mathrm{NF}-\kappa \mathrm{B})$ activation and the decreased expression of Bcl-2 induced by DDTC, as shown by NF- $\kappa \mathrm{B}$-dependent reporter gene expression assay and western blot analysis. Furthermore, treatment of nude mice with DDTC + TPA strongly inhibited the growth of PANC-1 xenograft tumors. The results of the present study indicate that the administration of TPA and DDTC in combination may be an effective strategy for inhibiting the growth of pancreatic cancer.
\end{abstract}

Correspondence to: Dr Xi Zheng, Department of Chemical Biology, Ernest Mario School of Pharmacy, Rutgers, The State University of New Jersey, 164 Frelinghuysen Road, Piscataway, NJ 08854, USA E-mail: xizheng@pharmacy.rutgers.edu

Key words: pancreatic cancer, 12- $O$-tetradecanoylphorbol-13-acetate, diethyldithiocarbamate, apoptosis, nuclear factor- $\kappa \mathrm{B}$

\section{Introduction}

Pancreatic cancer is one of the most aggressive types of cancer. It is estimated that this disease caused over 38,000 deaths in the United States in 2013 (1). Pancreatic cancer arises from the morphologically and genetically defined precursor lesions through a step-wise accumulation of genetic alterations. In the majority of patients diagnosed with the disease, symptoms do not develop until the tumor is either unresectable or metastatic, rendering it difficult to cure (2-4). Despite great advances in the treatment of cancer, pancreatic cancer is still the fourth most frequent cuase of cancer-related mortality in the Western world $(1,2)$. The 5-year survival for individuals with pancreatic cancer is $<5 \%$, and conventional treatment approaches, such as surgery, radiation, chemotherapy, or combinations of these, have had little effect on the course of this aggressive neoplasm (3-7). The low survival rate of patients points towards an increased need for the development of novel anticancer agents and effective combination therapies for the treatment of pancreatic cancer.

The phorbol ester, 12- $O$-tetradecanoylphorbol-13-acetate (TPA) (Fig. 1), is a major active constituent of the seed oil of Croton tiglium L., a leafy shrub of the Euphorbiaceae family that is native to Southeastern Asia. In previous studies by our group, we demonstrated the pharmacological activity of TPA in myeloid leukemia patients with an acceptable toxicity profile (8-10). Combinations with other agents have been shown to enhance the anticancer effects of TPA in myeloid leukemia and prostate cancer cells $(11,12)$. Studies that have been carried out by our laboratory team, as well as other investigators have demonstrated that TPA inhibits the growth and induces the apoptosis of cultured pancreatic cancer cells (13-17). The nuclear factor $-\kappa \mathrm{B}(\mathrm{NF}-\kappa \mathrm{B})$ transcription factor is constitutively activated in the majority of pancreatic cancers and is involved in the regulation of many aspects of tumor development and progression (18). Previous studies by our research team have indicated that the inhibition of NF- $\mathrm{BB}$ enhances the effects of TPA on leukemia and prostate cancer cells $(19,20)$. Combination with pharmacological inhibitors of $N F-\kappa B$ may thus be an 
effective approach with which to increase the inhibitory effects of TPA on pancreatic cells.

Diethyldithiocarbamate (DDTC) (Fig. 1), a member of the dithiocarbamate family, is a potent inhibitor of $\mathrm{NF}-\kappa \mathrm{B}(21,22)$. DDTC is a major metabolite of disulfiram, an agent used in the treatment of alcoholism (23-25). Many clinical aspects of DDTC, such as the treatment of metal toxicity and cancer, have been investigated $(26,27)$. Disulfiram, DDTC and pyrrolidine dithiocarbamate (PDTC) are well-known inhibitors of $\mathrm{NF}-\kappa \mathrm{B}$. These compounds inhibit I $\mathrm{B}$ phosphorylation, $\mathrm{NF}-\kappa \mathrm{B}$ nuclear translocation and proteasome degradation $(21,22,28,29)$. DDTC has also been shown to induce the apoptosis of cancer cells $(21,22,26)$. In addition, recent studies have demonstrated that a complex constituted by DDTC and copper inhibits the proliferation ofpancreatic cancer cells (30), and that DDTC synergistically enhances the effects of gemcitabine on pancreatic cells (31). Based on this evidence, we thus hypothesized that DDTC may inhibit the activation of $\mathrm{NF}-\kappa \mathrm{B}$ and may thus enhance the anticancer activity of TPA in pancreatic cancer cells.

The present study was undertaken to examine our hypothesis that DDTC enhances the growth inhibitory and apoptosis-promoting effects of TPA on pancreatic cancer cells. For this purpose, we determined the effects of DDTC and TPA alone or in combination on pancreatic cancer cells in conventional monolayer cultures, as well as in 3 dimensional (3D) cultures. In addition, the effects of TPA alone or in combination with DDTC on the growth of PANC-1 xenograft tumors in $\mathrm{NCr}$ nude mice were determined. To the best of our knowledge, the present study provides the first evidence that DDTC inhibits $\mathrm{NF}-\kappa \mathrm{B}$ activity, decreases the expression of Bcl-2 and enhances the inhibitory effects of TPA on pancreatic cancer cell growth in vitro and in vivo.

\section{Materials and methods}

Cells and reagents. The human pancreatic cancer cell lines, PANC-1, MIA PaCa-2 and BxPC-3, were obtained from the American Type Culture Collection (ATCC, Rockville, MD, USA). TPA was obtained from Alexis Co. (San Diego, CA, USA) and DDTC was from Sigma-Aldrich (St. Louis, MO, USA). The cells were maintained in Dulbecco's modified Eagle's medium (DMEM) containing 10\% fetal bovine serum (FBS) that was supplemented with penicillin $(100 \mathrm{U} / \mathrm{ml})$ streptomycin $(100 \mu \mathrm{g} / \mathrm{ml})$ and L-glutamine $(300 \mu \mathrm{g} / \mathrm{ml})$. The cultured cells were grown at $37^{\circ} \mathrm{C}$ in a humidified atmosphere of $5 \% \mathrm{CO}_{2}$ and were passaged twice a week.

Determination of the number of viable cells. The number of viable cells after each treatment was determined using a hemocytometer under a light microscope (Nikon Optiphot, Tokyo, Japan). Cell viability was determined by the trypan blue exclusion assay, which was performed by mixing $80 \mu \mathrm{l}$ of cell suspension and $20 \mu \mathrm{l}$ of $0.4 \%$ trypan blue solution for 2 min. Blue cells were counted as dead cells and the cells that did not absorb the dye were counted as live cells.

Assessment of apoptotic cells by morphological analysis and by the activation of caspase-3. Apoptosis was determined by the morphological assessment of the cells stained with propidium iodide using a fluorescence microscope (Nikon Eclipse TE200;
Nikon, Tokyo, Japan). Apoptotic cells were identified by classical morphological characteristics, including nuclear condensation, cell shrinkage and the formation of apoptotic bodies (20). The activation of caspase-3 was measured using an EnzoLyte AMC Caspase-3 Assay Fluorimetric kit (AnaSpec, Fremont, CA, USA) following the instructions of the manufacturer (32). Fluorescence intensity was measured using a Tecan Infinite M200 plate reader (Tecan US Inc., Durham, NC, USA).

$N F-\kappa B$-dependent reporter gene expression assay. $\mathrm{NF}-\kappa \mathrm{B}$ transcriptional activity was measured by $\mathrm{NF}-\kappa \mathrm{B}-$ luciferase reporter gene expression assay. The $\mathrm{NF}-\kappa \mathrm{B}-$ responsive luciferase construct was transiently transfected into the PANC-1 cells by using Lipofectamine ${ }^{\mathrm{TM}} 2000$ (Invitrogen Life Technologies, Grand Island, NY, USA) following the manufacturer's instructions. The cells were then treated with DDTC or TPA alone or in combination for $24 \mathrm{~h}$, and the NF- $\kappa \mathrm{B}$-luciferase activities were measured using the luciferase assay kits (E1500; Promega Madison, WI, USA) according to the manufacturer's instructions.

Western blot analysis. Following treatment with TPA, DDTC or a combination of both, the cell lysates were prepared as described in a previous study (12). Proteins were subjected to sodium dodecyl sulfate-polyacrylamide gel electrophoresis (SDS-PAGE) and subsequently transferred onto nitrocellulose membranes. After blocking the non-specific binding sites with blocking buffer, the membranes were incubated overnight at $4^{\circ} \mathrm{C}$ with Bcl-2 primary antibody (05-729; Millipore Corp., Billerica, MA, USA). $\beta$-actin was used as a loading control. Following the removal of the primary antibody, the membranes were washed 3 times with TBS (PBS containing $0.05 \%$ Tween20) buffer at room temperature and subsequently incubated with fluorochrome-conjugated secondary antibody (sc-3738; Santa Cruz Biotechnology, Inc., Santa Cruz, CA, USA). Final detection was performed using an Odyssey Infrared Imaging system (LI-COR Biosciences, Lincoln, NE, USA).

$3 D$ cell culture. The PANC-1 cells were mixed with Matrigel (Collaborative Research Inc., Bedford, MA, USA) on ice at a density of $0.5 \times 10^{5}$ cells $/ \mathrm{ml}$. The Matrigel containing the PANC-1 cells was placed on a 12 -well plate $(1 \mathrm{ml} /$ well) and incubated at $37^{\circ} \mathrm{C}$ for $2 \mathrm{~h}$ to allow the Matrigel to solidify. Subsequently, DMEM was added to each well on top of the gel. The cells were incubated for $24 \mathrm{~h}$ and then treated with DDTC or TPA alone or in combination once every other day. On day 10 , the 3D cultures were examined under a microscope (Nikon Optiphot; Nikon) for the determination of the formation of tissue-like structures.

Xenograft tumors in NCr nude mice. Male NCr nude mice (6-7 weeks old) were obtained from Taconic Farms Inc. (Germantown, NY, USA). The animals were housed in sterile filter-capped microisolator cages and provided with sterilized food and water. The PANC- 1 cells $\left(2 \times 10^{6}\right.$ cells/mouse $)$ suspended in 50\% Matrigel (Collaborative Research Inc.) in DMEM were injected subcutaneously into the right flank of the mice. When the tumors reached a moderate size $(0.6-1.0 \mathrm{~cm}$ in width and $0.6-1.0 \mathrm{~cm}$ in length), the mice received daily intraperitoneal (i.p.) injections with solvent (controls) which consisted of propylene glycol, polysorbate 80, benzyl alcohol, ethanol and water (40:0.5:1:10:48.5; control), TPA (50 ng/g 
Table I. Effects of TPA and DDTC alone or in combination on the apoptosis of PANC-1 cells.

\begin{tabular}{lcc}
\hline Treatment & Apoptotic cells $(\%)$ & Relative caspase-3 activity \\
\hline Control & $2.1 \pm 0.2$ & 1.0 \\
TPA $(0.16 \mathrm{nM})$ & $4.0 \pm 0.3$ & $1.7 \pm 0.2$ \\
TPA $(0.32 \mathrm{nM})$ & $7.2 \pm 0.3$ & $4.1 \pm 0.5$ \\
DDTC $(20 \mathrm{nM})$ & $5.6 \pm 0.4$ & $2.7 \pm 0.3$ \\
DDTC $(50 \mathrm{nM})$ & $10.7 \pm 1.1$ & $5.2 \pm 0.5$ \\
TPA $(0.16 \mathrm{nM})+$ DDTC $(20 \mathrm{nM})$ & $19.7 \pm 2.6^{\mathrm{a}}$ & $9.8 \pm 0.8^{\mathrm{a}}$ \\
TPA $(0.32 \mathrm{nM})+$ DDTC $(50 \mathrm{nM})$ & $32.5 \pm 2.4^{\mathrm{a}}$ & $13.0 \pm 1.0^{\mathrm{a}}$
\end{tabular}

PANC-1 cells were seeded at a density of $0.2 \times 10^{5}$ cells $/ \mathrm{ml}$ in cell culture dishes and incubated for $24 \mathrm{~h}$. The cells were then treated with TPA and DDTC alone or in combination for $72 \mathrm{~h}$. Apoptotic cells were determined by morphological assessment and by caspase- 3 assay. Statistical analysis using ANOVA with Tukey-Kramer multiple comparison test revealed that the differences in the number of apoptotic cells between the group treated with the combination of both agents and the groups treated with either TPA or DDTC alone were statistically significant. ${ }^{a}<<0.001$. TPA, 12-O-tetradecanoylphorbol-13-acetate; DDTC, diethyldithiocarbamate.

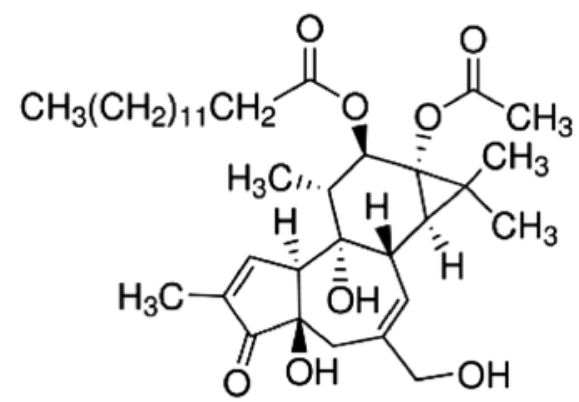

12-O-Tetradecanoylphorbol-13-acetate (TPA)<smiles>CCN(CC)C(=S)SC</smiles>

\section{Diethyldithiocarbamate (DDTC)}

Figure 1. Structures of 12- $O$-tetradecanoylphorbol-13-acetate (TPA) and diethyldithiocarbamate (DDTC).

body weight/day), DDTC (30 $\mu \mathrm{g} / \mathrm{g}$ body weight/day) or a combination of TPA (50 ng/g/day) and DDTC (30 $\mu \mathrm{g} / \mathrm{g} /$ day) for 28 days. Tumor size (length $\mathrm{x}$ width) and body weight were measured 3 times a week. The animal experiments were carried out under an Institutional Animal Care and Use Committee (IACUC)-approved protocol (Rutgers University).

Tumor cell proliferation. The proliferation of the PANC-1 tumor cells was determined by the expression of proliferating cell nuclear antigen (PCNA) using immunohistochemical staining. In brief, tumors were excised from each mouse and weighed at the end of the experiment. Tumor tissues were fixed in buffered formalin for $24 \mathrm{~h}$ and then with ethanol for $48 \mathrm{~h}$. Paraffin blocks of tumor tissues were prepared and paraffin sections of tumor tissues were processed for immunohistochemical staining. The sections were incubated with PCNA antibody (MAB424; Millipore Corp.) for $1 \mathrm{~h}$ at room temperature. The sections were then incubated with a biotinylated secondary antibody for $30 \mathrm{~min}$ followed by incubation with horseradish peroxidase conjugated-avidin solution for $30 \mathrm{~min}$ using the Elite ABC kit (PK-6100; Vector Laboratories, Burlingame, CA, USA). PCNA staining in the tumor cells (brown color in nucleus) was examined under a microscope (Nikon Optiphot; Nikon). At least 1,000 cells were counted for each section.

Statistical analysis. The analysis of variance (ANOVA) method and the Tukey-Kramer test were used for the comparison of viable cells, apoptosis and NF- $\kappa \mathrm{B}$ luciferase activity in the cultured pancreatic cancer cells. These statistical methods were also used for the comparison of tumor size and body weight among the different treatment groups in the in vivo experiments. A P-value $<0.05$ was considered to indicate a statistically signficant difference.

\section{Results}

Effects of TPA and DDTC on the growth and apoptosis of pancreatic cancer cells. The effects of TPA and DDTC alone or in combination on the growth of human pancreatic cancer cells were determined using the trypan blue exclusion assay. Treatment of the human prostate cancer cells, PANC-1, MIA PaCa-2 and BxPC-3, with TPA or DDTC alone resulted in cancer cell growth inhibition in a concentrationdependent manner (Fig. 2A and B). The PANC-1 cells were more sensitive than the MIA PaCa- 2 and $\mathrm{BxPC}-3$ cells to the growth inhibitory effects induced by TPA and DDTC (Fig. 2A and B). The combination of DDTC and TPA had more potent inhibitory effects on the growth of the cells than either agent alone (Fig. 2C). The number of viable PANC-1, MIA PaCa-2 and BxPC-3 cells was significantly lower in the group treated with the combination of both agents than in the groups treated with either TPA or DDTC alone $(\mathrm{P}<0.001)$. We also observed the morphology of the PANC-1 cells treated with TPA and/or DDTC under a phase-contrast microscope (Fig. 2D-G). The 

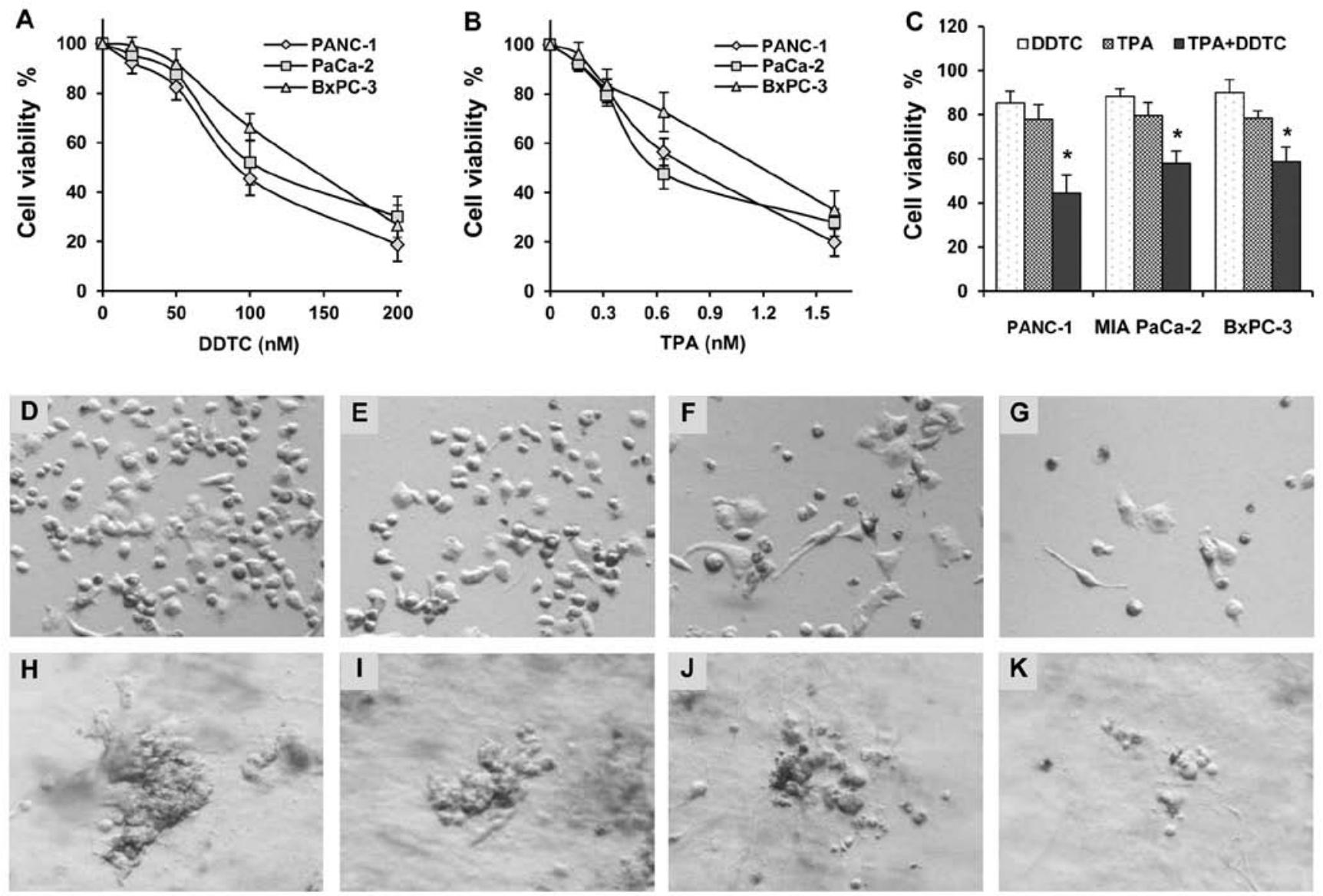

Figure 2. Effects of 12-O-tetradecanoylphorbol-13-acetate (TPA) and diethyldithiocarbamate (DDTC) alone or in combination on human pancreatic cancer cells. (A-C) PANC-1, MIA PaCa-2 and Bx-PC-3 cells were seeded at a density of $0.2 \times 10^{5}$ cells $/ \mathrm{ml}$ in cell culture dishes and incubated for $24 \mathrm{~h}$. The cells were then treated with TPA or DDTC alone or in combination for $72 \mathrm{~h}$. The number of viable cells was determined by the trypan blue exclusion assay. "P<0.001, compared to treatment with either agent alone. (D-G) Morphology of PANC-1 cells treated with TPA or DDTC alone or in combination as described above. Representative micrographs of PANC-1 cells in the (D) control, (E) DDTC-treated, (F) TPA-treated and (G) TPA + DDTC-treated groups are shown. (H-K) Morphology of PANC-1 cells in 3D culture. PANC-1 cells were seeded at a density of $0.5 \times 10^{5}$ cells/ml in Matrigel in a 12-well plate (1 ml/well) and incubated for $2 \mathrm{~h}$ to allow the gel to solidify. DMEM was added on top of the gel $(1 \mathrm{ml} /$ well), and the cells were incubated for $24 \mathrm{~h}$. The cells were then treated with TPA and DDTC alone or in combination once every other day for 10 days. Representative micrographs of PANC-1 cell 3D cultures in the (H) control, (I) DDTC-treated, (J) TPA-treated and $(\mathrm{K})$ TPA + DDTC-treated groups are shown.

effects of TPA and/or DDTC on the apoptosis of the PANC-1 cells were determined by morphological assessment and caspase-3 assay. Treatment with TPA or DDTC alone resulted in a moderate increase in the number of apoptotic cells (Table I). The combination treatments with TPA and DDTC at various concentrations had a more potent promoting effect on apoptosis than treatment with either agent alone (Table I).

Effects of TPA and DDTC on PANC-1 cells in $3 D$ culture. A 3D cell culture model was used to determine the effects of TPA and DDTC alone or in combination on the formation and growth of 3D tissue-like structures. The PANC-1 cells formed a tissue-like morphology in 3D culture in the extracellular matrix gel (Fig. 2H). Treatment with DDTC or TPA alone had an inhibitory effect on the formation and growth of tissue-like structures (Fig. 2I and J). DDTC and TPA in combination had a more potent inhibitory effect on the formation of tissue-like structures (Fig. 2K).

Effects of TPA and/or DDTC on NF- $\mathrm{B}$ activation and the expression of Bcl-2. The effects of TPA and DDTC alone or in combination on the activation of NF- $\mathrm{kB}$ were determined by luciferase reporter gene expression assay. Treatment of the PANC-1 cells with DDTC resulted in a marked decrease in NF- $\kappa \mathrm{B}$ activity, while treatment with TPA alone caused an increase in the activity of NF- $\kappa B$ (Fig. 3). The stimulatory effects of TPA on NF- $\mathrm{KB}$ were markedly suppressed by treatment with DDTC (combination treatment; Fig. 3). The expression of Bcl-2, a downstream target of the NF- $\kappa B$ pathway was measured by western blot analysis. Treatment with TPA alone had little or no effect on the level of Bcl-2 (Fig. 4). However, treatment of the PANC-1 cells with DDTC alone or in combination with TPA resulted in a marked decrease in the level of Bcl-2 (Fig. 4).

Inhibitory effect of TPA or DDTC alone or in combination on the grow th of PANC-1 xenograft tumors in NCr nude mice. $\mathrm{NCr}$ nude mice bearing PANC-1 xenograft tumors were treated with daily an i.p. injection of TPA or DDTC alone or a combination of both for 28 days. Tumor growth was also observed in the control group (Fig. 5A). Treatment with i.p. injections of TPA in combination with DDTC had a more prominent inhibitory 


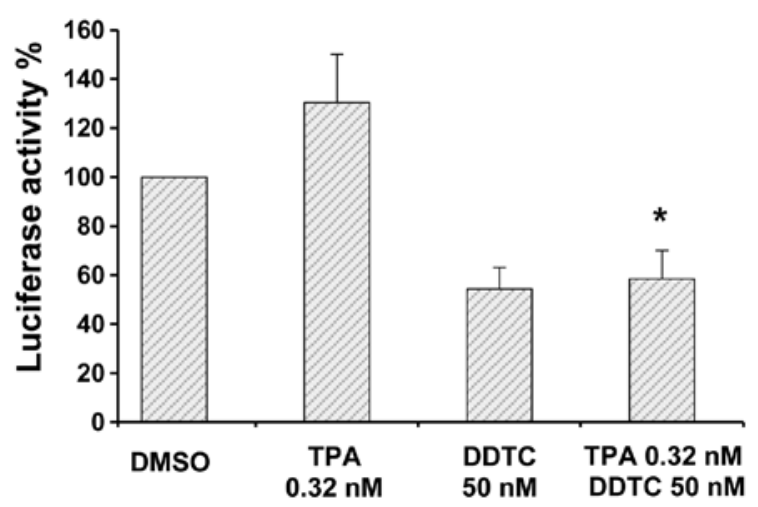

Figure 3. Effects of 12-O-tetradecanoylphorbol-13-acetate (TPA) and/or diethyldithiocarbamate (DDTC) on nuclear factor- $\kappa \mathrm{B}(\mathrm{NF}-\kappa \mathrm{B})$ activity. PANC-1 cells were seeded at a density of $0.2 \times 10^{6}$ cells $/ \mathrm{ml}$ in medium in $60 \mathrm{~mm}$ culture dishes $(5 \mathrm{ml} / \mathrm{dish})$ and incubated for $24 \mathrm{~h}$. The cells were then transfected with a NF- $\kappa$ B-luciferase construct using Lipofectamine ${ }^{\mathrm{TM}} 2000$ (LF2000; Invitrogen Life Technologies). The cells were treated with TPA alone or in combination with DDTC for $24 \mathrm{~h}$. The luciferase activity was determined using a luciferase assay kits (E1500; Promega). Each value represents the mean \pm SE from 3 separate experiments. $\mathrm{P}<0.01$ compared to treatment with TPA alone.

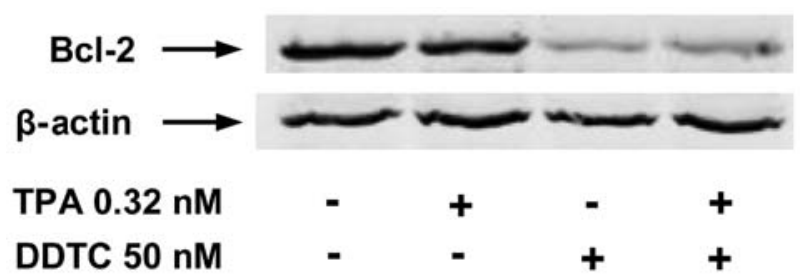

Figure 4. Effect of 12-O-tetradecanoylphorbol-13-acetate (TPA) and/or diethyldithiocarbamate (DDTC) on the level of Bcl-2 in PANC-1 cells. PANC-1 cells were seeded at a density of $1 \times 10^{5}$ cells $/ \mathrm{ml}$ in medium and incubated for $24 \mathrm{~h}$. The cells were then treated with TPA or DDTC alone or in combination for $48 \mathrm{~h}$. Bcl-2 expression was measured by western blot analysis using an anti-Bcl-2 antibody (05-729; Millipore Corp.).

effect on the growth of PANC-1 tumors than either agent used individually (Fig. 5A). Statistical analysis using ANOVA with the Tukey-Kramer multiple comparison test revealed that the differences in the percentage of the initial tumor size at the end of the experiment were statistically significant between the control group and the group treated with the combination of both agents $(\mathrm{P}<0.001)$, as well as between the control group and the TPA-treated group $(\mathrm{P}<0.05)$. The percentage of the initial tumor size in the group treated with the combination of both agents was significantly smaller than that in the groups treated with TPA alone $(\mathrm{P}<0.05)$ or DDTC alone $(\mathrm{P}<0.01)$. Treatment with TPA or DDTC alone or in combination did not significantly affect the body weight of the animals (Fig. 5B). Statistical analysis using ANOVA with the Tukey-Kramer multiple comparison test revealed that the difference in the percentage of the initial body weight between any 2 groups was not statistically significant $(\mathrm{P}>0.05)$.

Inhibitory effects of TPA and/or DDTC on cell proliferation in PANC-1 tumors. The effects of TPA and DDTC on PANC-1 tumor growth were investigated by determining the expression of PCNA in the tumor cells. Immunohistochemistry of PCNA
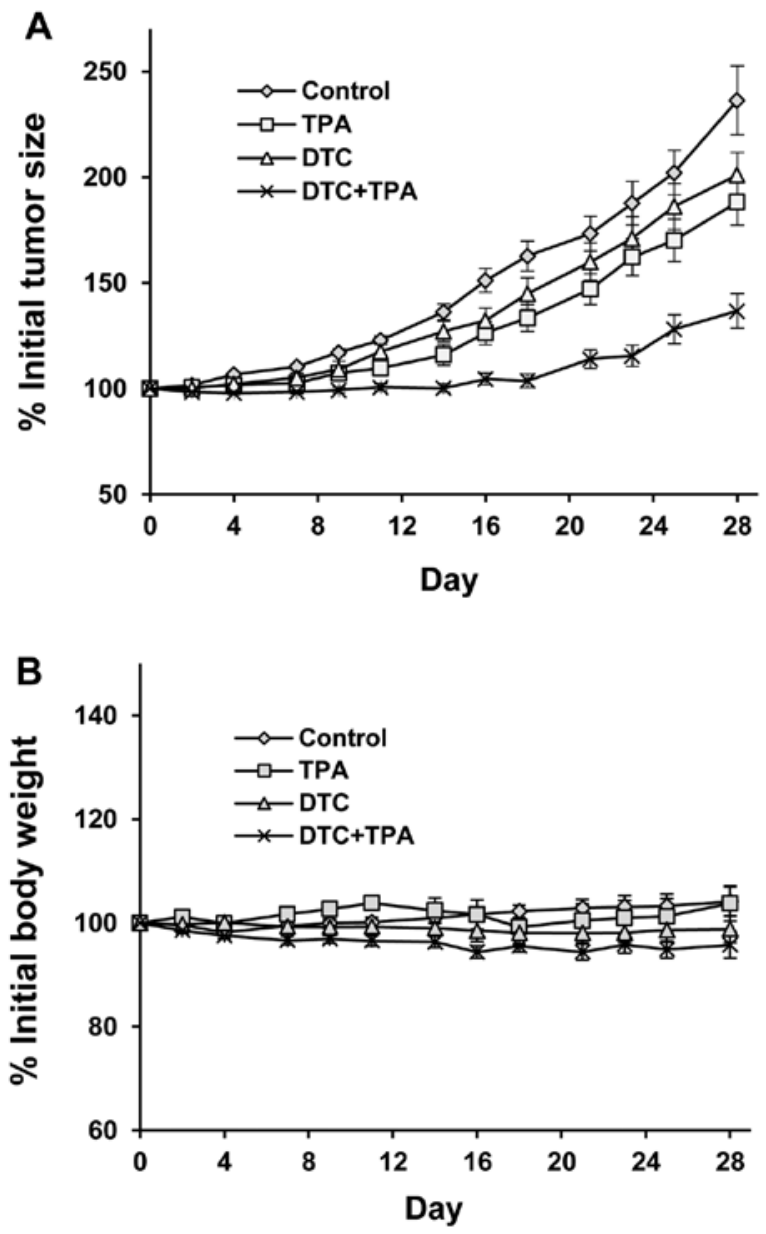

Figure 5. Effects of intraperitoneal injections of 12-O-tetradecanoylphorbol13-acetate (TPA) or diethyldithiocarbamate (DDTC) alone or in combination on (A) the growth of PANC-1 tumors and (B) the body weight of $\mathrm{NCr}$ nude mice. Male NCr nude mice were injected subcutaneously with PANC-1 cells $\left(2.0 \times 10^{6} \mathrm{cells} / \mathrm{mouse}\right)$. Mice with established tumors $(0.6-1.0 \mathrm{~cm}$ wide and $0.6-1.0 \mathrm{~cm}$ long) received daily intraperitoneal injections of TPA or DDTC alone or in combination for 28 days. Tumor size (length $\mathrm{x}$ width) and body weight were measured and expressed as a percentage of the initial tumor size or a percentage of the initial body weight. Each value represents the mean \pm SE.

in the paraffin-embedded sections of PANC-1 tumors revealed that treatment of the mice with TPA or DDTC alone reduced the number of PCNA-positive cells in the tumors (Fig. 6B and C). Combined treatment with TPA and DDTC had a more potent inhibitory effect on the number of PCNA-positive cells than treatment with either agent alone (Fig. 6D). The differences in the number of PCNA-positive cells were statistically significant between the group treated with the combination of both agents and the group treated with TPA alone $(\mathrm{P}<0.01)$, as well as between the group treated with the combination of both agents and the group treated with DDTC alone $(\mathrm{P}<0.01$; Fig. $6 \mathrm{E})$.

\section{Discussion}

Although previous studies have shown that treatment with TPA or DDTC alone inhibits pancreatic cancer cell growth $(13-17,30,31)$, to the best of our knowledge, the effects and mechanisms of action of these two agents in combination on the growth and the apoptosis of pancreatic cancer cells 
A

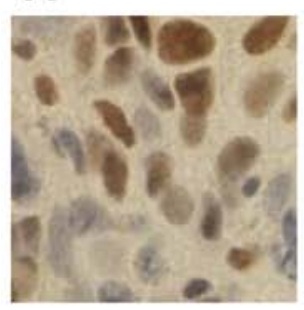

B

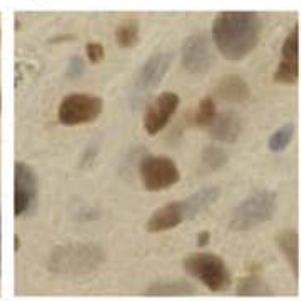

C

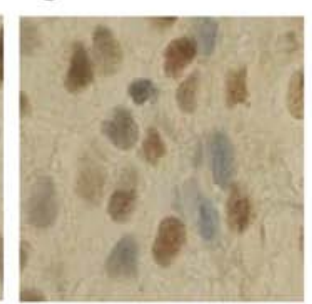

D

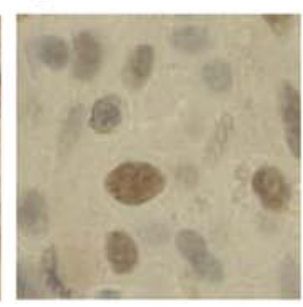

$E$

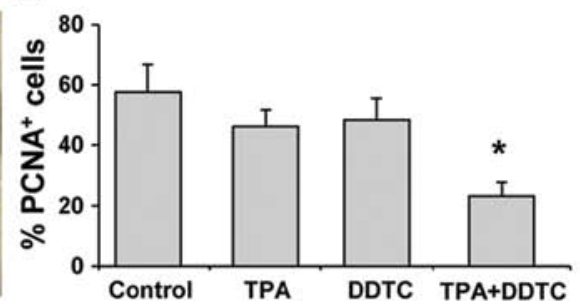

Figure 6. Effect of treatment 12- $O$-tetradecanoylphorbol-13-acetate (TPA) or diethyldithiocarbamate (DDTC) alone or in combination on the expression of proliferating cell nuclear antigen (PCNA) in PANC-1 tumors. Immunohistochemistry with a PCNA antibody was performed on the paraffin-embedded sections of PANC-1 tumors collected from the mice following treatment as described in Fig. 5. Representative micrographs of PCNA immunostaining in tumors from the (A) control, (B) TPA-treated, (C) DDTC-treated and (D) TPA + DDTC-treated groups are shown. PCNA positive cells were determined using a microscope (Nikon Optiphot) and (E) expressed as a percentage of PCNA-positive cells. Each value represents the mean $\pm \mathrm{SE}$. $\mathrm{P}<0.01$, compared to treatment with either agent alone.

in vitro and in vivo have not yet been reported. In the present study, we demonstrated that TPA in combination with DDTC exerted potent growth inhibitory and apoptosis-promoting effects on pancreatic cancer cells. We also demonstrated that the combination of both agents markedly inhibited the growth of PANC-1 xenograft tumors in NCr nude mice. To the best of our knowledge, this is the first study indicating a strong inhibitory effect of the combination of TPA and DDTC on pancreatic cancer cell growth.

In the present study, we determined the effects of TPA and DDTC alone or in combination on PANC-1 cells in 3D cultures. Compared to conventional 2D monolayer cell cultures, the $3 \mathrm{D}$ culture system mimics the structural architecture and functional differentiation of tumor tissues $(33,34)$. It is well known that cell-cell and cell-matrix interactions within the $3 \mathrm{D}$ microenvironment are important to the physiological function and response of cancer cells to anticancer agents $(33,34)$. In the present study, we found that PANC-1 cells formed a 3D tissue-like morphology in the extracellular matrix Matrigel. Treatment of the PANC-1 cells with TPA and DDTC in combination had a more prominent inhibitory effect on the formation of a tissue-like morphology in the 3D cultures than treatment with either agent alone.

The inhibition of NF- $\kappa \mathrm{B}$ activation has been found to enhance the anticancer activities of TPA in leukemia (19) and prostate cancer cells (20). NF- $\mathrm{NB}$ is an important cellular regulator of growth and apoptosis. This transcription factor has been connected with multiple aspects of oncogenesis, including the control of apoptosis, the cell cycle, cell differentiation and cell migration $(18,35,36)$. A number of studies have indicated that the activation of NF- $\kappa \mathrm{B}$ suppresses cell death pathways and that the activation of $\mathrm{NF}-\kappa \mathrm{B}$ is required to protect cells from the apoptotic cascade. Chemotherapeutic agents, such as 5-fluorouracil (5-FU), etoposide, docetaxel and gemcitabine have been reported to activate NF- $\mathrm{NB}$ in cancer cells (37-40). The activation of $\mathrm{NF}-\kappa \mathrm{B}$ may be a protective response to treatment with chemotherapeutic agents, while the inhibition of NF- $\kappa \mathrm{B}$ has been shown to enhance the anticancer activity of chemotherapeutic agents (37-40). In the present study, luciferase reporter assay revealed that TPA increased NF- $\kappa \mathrm{B}$ activity. Treatment with DDTC markedly inhibited NF- $\kappa \mathrm{B}$ activity, decreased the expression of $\mathrm{Bcl}-2$ and enhanced the effects of TPA on the PANC-1 cells. These findings indicate that TPA in combination with pharmacological inhibitors of
$\mathrm{NF}-\kappa \mathrm{B}$ may thus be an effective strategy for improving the therapeutic efficacy of TPA in pancreatic cancer.

Previous research by our team demonstrated that the peak blood levels of TPA \pm SD value in several patients who received an intravenous (i.v.) infusion of TPA $\left(0.125 \mathrm{mg} / \mathrm{m}^{2}\right)$ was $1.75 \pm 0.55 \mathrm{ng} / \mathrm{ml}$ and ranged between 0.3 and $5.2 \mathrm{ng} / \mathrm{ml}$. The concentrations of TPA used to obtain an inhibitory effect on pancreatic cancer cells in the present study $(0.1-1 \mathrm{ng} / \mathrm{ml}$; $0.16-1.6 \mathrm{nM})$ are clinically achievable $(9,41)$. Concentrations of DDTC used in some previous in vitro studies have ranged from nanomolar $(\mathrm{nM})$ to micromolar $(\mu \mathrm{M})$ and the treatment time has varied between $30 \mathrm{~min}$ to $24 \mathrm{~h}(21,26,44,45)$. Instead of using a high concentration and a short treatment time, we found that treatment with lower concentrations (50-200 nM) of DDTC for $72 \mathrm{~h}$ markedly inhibited the growth and induced the apoptosis of pancreatic cancer cells. The concentrations of DDTC used in the present study were much lower than the blood levels of DDTC in humans $(42,43)$.

A strong inhibitory effect of TPA and DDTC on the growth of PANC-1 xenograft tumors in nude mice was observed in the present study. Treatment of $\mathrm{NCr}$ nude mice with i.p. injections of TPA and DDTC in combination more potently inhibited the growth of PANC-1 tumors than treatment with either agent alone. Immunohistochemical analysis revealed that cancer cell growth (proliferation), as reflected by the expression of PCNA, was significantly lower in the tumors from the mice treated with TPA + DDTC than in the tumors from the mice treated with either TPA or DDTC alone. At the doses used in the present study, TPA and DDTC alone or in combination appeared to be non-toxic as no differences in body weight were observed in the animals following treatment. Furthermore, no abnormalities were observed in the major organs at the end of the experiment (data not shown). Further studies are required to establish the plasma levels of TPA and DDTC in relation to their combined inhibitory effect on pancreatic tumors in suitable animal models.

In conclusion, in the present study, we demonstrated that TPA in combination with DDTC markedly inhibited pancreatic cancer cell growth and induced the apoptosis of human pancreatic cancer cells. In addition, we found that treatment of NCr nude mice with a combination of TPA and DDTC inhibited the growth of xenograft PANC-1 tumors. TPA in combination with pharmacological inhibitors of $\mathrm{NF}-\kappa \mathrm{B}$, such as DDTC, may thus be an effective approach with which to inhibit the growth of pancreatic cancer. 


\section{Acknowledgements}

The present study was supported by grants from the Guangdong Province Leadership Project, the Rutgers Cancer Institute of New Jersey (CCSG P30-CA072720 RSD), the China National Science Foundation (81272452 and 21102020), the Guangdong Province Project (2012B091100342), and the Guangzhou City Project (2013J4500014). The authors dedicate this study to Dr Allan H. Conney, an outstanding and widely recognized cancer researcher who passed away on September 10, 2013.

\section{References}

1. Siegel R, Naishadham D and Jemal A: Cancer statistics, 2013. CA Cancer J Clin 63: 11-30, 2013.

2. Zhang DX, Dai YD, Yuan SX and Tao L: Prognostic factors in patients with pancreatic cancer. Exp Ther Med 3: 423-432, 2012

3. Cao H, Le D and Yang LX: Current status in chemotherapy for advanced pancreatic adenocarcinoma. Anticancer Res 33: $1785-1791,2013$

4. Arslan C and Yalcin S: Current and future systemic treatment options in metastatic pancreatic cancer. J Gastrointest Oncol 5: 280-295, 2014

5. Di Marco M, Di Cicilia R, Macchini M, Nobili E, Vecchiarelli S, Brandi G and Biasco G: Metastatic pancreatic cancer: Is gemcitabine still the best standard treatment? (Review). Oncol Rep 23: 1183-1192, 2010.

6. De Felice F, Musio D, Raffetto N and Tombolini V: Neoadjuvant strategy as initial treatment in resectable pancreatic cancer: concrete evidence of benefit. Anticancer Res 34: 4673-4676, 2014.

7. Yutani S, Komatsu N, Yoshitomi M, Matsueda S, Yonemoto K, Mine T, Noguchi M, Ishihara Y, Yamada A, Itoh K and Sasada T: A phase II study of a personalized peptide vaccination for chemotherapy-resistant advanced pancreatic cancer patients. Oncol Rep 30: 1094-1100, 2013.

8. Han ZT, Zhu XX, Yang RY, Sun JZ, Tian GF, Liu XJ, Cao GS, Newmark HL, Conney AH and Chang RL: Effect of intravenous infusions of 12-O-tetradecanoylphorbol-13-acetate (TPA) in patients with myelocytic leukemia: preliminary studies on therapeutic efficacy and toxicity. Proc Natl Acad Sci USA 95: 5357-5361, 1998.

9. Strair RK, Schaar D, Goodell L, Aisner J, Chin KV, Eid J, Senzon R, Cui XX, Han ZT, Knox B, Rabson AB, Chang R and Conney A: Administration of a phorbol ester to patients with hematological malignancies: preliminary results from a phase I clinical trial of 12-O-tetradecanoylphorbol-13-acetate. Clin Cancer Res 8: 2512-2518, 2002.

10. Schaar D, Goodell L, Aisner J, Cui XX, Han ZT, Chang R, Martin J, Grospe S, Dudek L, Riley J, Manago J, Lin Y, Rubin EH, Conney A and Strair RK: A phase I clinical trial of 12-O-tetradecanoylphorbol-13-acetate for patients with relapsed/refractory malignancies. Cancer Chemother Pharmacol 57: 789-795, 2006.

11. Zheng X, Ryan A, Patel N, Klemons S, Hansson A, Shih WJ, Lin Y, Huberman E, Chang RL and Conney AH: Synergistic stimulatory effect of 12-O-tetradecanoylphorbol-13-acetate and capsaicin on macrophage differentiation in HL-60 and HL-525 human myeloid leukemia cells. Int J Oncol 26: 441-448, 2005.

12. Zheng X, Chang RL, Cui XX, Avila GE, Hebbar V, Garzotto M, Shih WJ, Lin Y, Lu SE, Rabson AB, Kong AN and Conney AH: Effects of 12-O-tetradecanoylphorbol-13-acetate (TPA) in combination with paclitaxel (Taxol) on prostate Cancer LNCaP cells cultured in vitro or grown as xenograft tumors in immunodeficient mice. Clin Cancer Res 12: 3444-3451, 2006.

13. Avila GE, Zheng X, Cui XX, Ryan AD, Hansson A, Suh J, Rabson AB, Chang RL, Shih WJ, Lin Y, Crowell P, Lu YP, Lou YR and Conney AH: Inhibitory effects of 12-O-tetradecanoylphorbol13-acetate alone or in combination with all-trans retinoic acid on the growth of cultured human pancreas cancer cells and pancreas tumor xenografts in immunodeficient mice. J Pharmacol Exp Ther 315: 170-187, 2005.

14. Bond JA, Gescher AJ, Verschoyle RD, Lemoine NR, Errington R, Wiltshire M, Smith PJ and Wynford Thomas D: Cytotoxic action of phorbol esters on human pancreatic cancer cells. Int J Cancer 121: 1445-1454, 2007.
15. Salabat MR, Ding XZ, Flesche JB, Ujiki MB, Robin TP, Talamonti MS, Bell RH Jr and Adrian TE: On the mechanisms of 12-O-tetradecanoylphorbol-13-acetate-induced growth arrest in pancreatic cancer cells. Pancreas 33: 148-155, 2006.

16. Detjen KM, Brembeck FH, Welzel M, Kaiser A, Haller H, Wiedenmann B and Rosewicz S: Activation of protein kinase $\mathrm{C}$ alpha inhibits growth of pancreatic cancer cells via p21(cip)-mediated G(1) arrest. J Cell Sci 113: 3025-3035, 2000.

17. Zheng X, Cui XX, Gao Z, Verano M,Huang MT, Liu Y, Rabson AB and Conney AH: Effects of 12-O-tetradecanoylphorbol-13acetate in combination with gemcitabine on Panc-1 pancreatic cancer cells cultured in vitro or Panc-1 tumors grown in immunodeficient mice. Int J Oncol 41: 2269-2275, 2012.

18. Carbone $\mathrm{C}$ and Melisi D: NF- $\mathrm{kB}$ as a target for pancreatic cancer therapy. Expert Opin Ther Targets 16 (Suppl 2): S1-S10, 2012.

19. Hansson A, Marín YE, Suh J, Rabson AB, Chen S, Huberman E, Chang RL, Conney $\mathrm{AH}$ and Zheng $\mathrm{X}$ : Enhancement of TPA-induced growth inhibition and apoptosis in myeloid leukemia cells by BAY 11-7082, an NF-kappaB inhibitor. Int J Oncol 27: 941-948, 2005.

20. Zheng X,Chang RL,Cui XX,Avila G,Huang MT,Liu Y,Kong AN, Rabson $\mathrm{AB}$ and Conney AH: Inhibition of NF-kappaB by (E)3-[(4-methylphenyl)-sulfonyl]-2-propenenitrile (BAY11-7082; BAY) is associated with enhanced 12-O-tetradecanoylphorbol13-acetate-induced growth suppression and apoptosis in human prostate cancer PC-3 cells. Int J Oncol 32: 257-264, 2008.

21. Matsuno T, Kariya R, Yano S, Morino-Koga S, Taura M, Suico MA, Shimauchi Y, Matsuyama S, Okamoto Y, Shuto T, Kai $\mathrm{H}$ and Okada S: Diethyldithiocarbamate induces apoptosis in HHV-8-infected primary effusion lymphoma cells via inhibition of the NF-кB pathway. Int J Oncol 40: 1071-1078, 2012.

22. Cvek B and Dvorak Z: Targeting of nuclear factor-kappaB and proteasome by dithiocarbamate complexes with metals. Curr Pharm Des 13: 3155-3167, 2007.

23. Suh JJ, Pettinati HM, Kampman KM and O'Brien CP: The status of disulfiram: a half of a century later. J Clin Psychopharmacol 26: 290-302, 2006.

24. Eneanya DI, Bianchine JR, Duran DO and Andresen BD: The actions of metabolic fate of disulfiram. Annu Rev Pharmacol Toxicol 21: 575-596, 1981.

25. Langeland BT and McKinley-McKee JS: The effects of disulfiram on equine hepatic alcohol dehydrogenase and its efficiency against alcoholism: vinegar effect. Alcohol Alcohol 31: 75-80, 1996.

26. Pang H, Chen D, Cui QC and Dou QP: Sodium diethyldithiocarbamate, an AIDS progression inhibitor and a copper-binding compound, has proteasome-inhibitory and apoptosis-inducing activities in cancer cells. Int J Mol Med 19: 809-816, 2007.

27. Bradberry SM and Vale JA: Therapeutic review: do diethyldithiocarbamate and disulfiram have a role in acute nickel carbonyl poisoning? J Toxicol Clin Toxicol 37: 259-264, 1999.

28. Lövborg H, Oberg F, Rickardson L, Gullbo J, Nygren P and Larsson R: Inhibition of proteasome activity, nuclear factor-KappaB translocation and cell survival by the antialcoholism drug disulfiram. Int J Cancer 118: 1577-1580, 2006.

29. Zhang JJ, Xu ZM, Zhang CM, Dai HY, Ji XQ, Wang XF and Li C: Pyrrolidine dithiocarbamate inhibits nuclear factor- $\kappa \mathrm{B}$ pathway activation, and regulates adhesion, migration, invasion and apoptosis of endometriotic stromal cells. Mol Hum Reprod 17: 175-181, 2011.

30. Han J, Liu L, Yue X, Chang J, Shi W and Hua Y: A binuclear complex constituted by diethyldithiocarbamate and copper(I) functions as a proteasome activity inhibitor in pancreatic cancer cultures and xenografts. Toxicol Appl Pharmacol 273: 477-483, 2013.

31. Dalla PE, Donadelli M, Costanzo C, Zaniboni T, Dando I, Franchini M, Arpicco S, Scarpa A and Palmieri M: Gemcitabine response in pancreatic adenocarcinoma cells is synergistically enhanced by dithiocarbamate derivatives. Free Radic Biol Med 50: 926-933, 2011.

32. Wei X, Du ZY, Cui XX, Verano M, Mo RQ, Tang ZK, Conney AH, Zheng $X$ and Zhang $K$ : Effects of cyclohexanone analogues of curcumin on growth, apoptosis and NF- $\kappa \mathrm{B}$ activity in PC-3 human prostate cancer cells. Oncol Lett 4: 279-284, 2012.

33. Tsunoda T, Ishikura S, Doi K, Matsuzaki H, Iwaihara Y and Shirasawa S: Resveratrol induces luminal apoptosis of human colorectal cancer HCT116 cells in three-dimensional culture. Anticancer Res 34: 4551-4555, 2014. 
34. Akeda K, Nishimura A, Satonaka H, Shintani K, Kusuzaki K Matsumine A,Kasai Y,Masuda KandUchida A: Three-dimensional alginate spheroid culture system of murine osteosarcoma. Oncol Rep 22: 997-1003, 2009.

35. Zhang $\mathrm{Z}$ and Rigas $\mathrm{B}$ : NF- $\kappa \mathrm{B}$, inflammation and pancreatic carcinogenesis: NF- $\mathrm{BB}$ as a chemoprevention target (Review). Int J Oncol 29: 185-192, 2006.

36. Hu YQ, Si LJ, Ye ZS, Lin ZH and Zhou JP: Inhibitory effect of ARHI on pancreatic cancer cells and NF- $\kappa B$ activity. Mol Med Rep 7: 1180-1184, 2013

37. Kwon OH, Kim JH, Kim SY and Kim YS: TWEAK/Fn14 signaling mediates gastric cancer cell resistance to 5-fluorouracil via NF-кB activation. Int J Oncol 44: 583-590, 2014.

38. Kaewpiboon C, Srisuttee R, Malilas W, Moon J, Kaowinn S, Cho IR, Johnston RN, Assavalapsakul W and Chung YH: Extract of Bryophyllum laetivirens reverses etoposide resistance in human lung A549 cancer cells by downregulation of NF- $\kappa \mathrm{B}$. Oncol Rep 31: 161-168, 2014

39. Fujioka S, Son K, Onda S, Schmidt C, Scrabas GM, Okamoto T, Fujita T, Chiao PJ and Yanaga K: Desensitization of NFkB for overcoming chemoresistance of pancreatic cancer cells to TNF- $\alpha$ or paclitaxel. Anticancer Res 32: 4813-4821, 2012.

40. Zhang W, Chen H, Liu DL, Li H, Luo J, Zhang JH, Li Y, Chen KJ, Tong HF and Lin SZ: Emodin sensitizes the gemcitabine-resistant cell line Bxpc-3/Gem to gemcitabine via downregulation of $\mathrm{NF}-\kappa \mathrm{B}$ and its regulated targets. Int J Oncol 42: 1189-1196, 2013.
41. Cui XX, Chang RL, Zheng X, Woodward D, Strair R and Conney AH: A sensitive bioassay for measuring blood levels of 12-O-tetradecanoylphorbol-13-acetate (TPA) in patients: preliminary pharmacokinetic studies. Oncol Res 13: 169-174, 2002.

42. Gandara DR, Nahhas WA, Adelson MD, Lichtman SM, Podczaski ES, Yanovich S, Homesley HD, Braly P, Ritch PS, Weisberg SR, et al: Randomized placebo-controlled multicenter evaluation of diethyldithiocarbamate for chemoprotection against cisplatin-induced toxicities. J Clin Oncol 13: 490-496, 1995.

43. Qazi R, Chang AY, Borch RF, Montine T, Dedon P, Loughner J and Bennett JM: Phase I clinical and pharmacokinetic study of diethyldithiocarbamate as a chemoprotector from toxic effects of cisplatin. J Natl Cancer Inst 80: 1486-1488, 1988.

44. Mashiba $\mathrm{H}$ and Matsunaga K: Augmented inhibition of MethA tumor cell proliferation in combined use of diethyldithiocarbamate with catalase or by a nondialysable fraction from co-incubation. Toxicol Lett 66: 97-104, 1993.

45. Han YH, Moon HJ, You BR, Kim SZ, Kim SH and Park WH: The effects of buthionine sulfoximine, diethyldithiocarbamate or 3-amino-1,2,4-triazole on propyl gallate-treated HeLa cells in relation to cell growth, reactive oxygen species and glutathion. Int J Mol Med 24: 261-268, 2009. 